Sari Pediatri, Vol. 5, No. 1, Juni 2003: $21-26$

\title{
Masalah Nutrisi pada Thalassemia
}

\author{
Luszy Arijanty, Sri S Nasar
}

Gangguan pertumbuhan pada thalassemia disebabkan oleh banyak faktor antara lain faktor nutrisi. Gangguan pertumbuhan akibat kekurangan gizi dapat menyebabkan perawakan pendek. Nutrisi yang adekuat sangat penting untuk pasien thalassemia sebagai modalitas dalam pengobatan jangka panjang dan untuk mencegah gangguan gizi, gangguan pertumbuhan, perkembangan pubertas dan defisiensi imun. Asupan nutrisi yang dianjurkan pada thalassemia adalah tinggi kalori, protein, kalium, seng, vitamin $\mathrm{A}, \mathrm{D}, \mathrm{E}$, rendah besi sedangkan vitamin $\mathrm{C}$ harus dikurangi karena dapat meningkatkan absorpsi besi. Suplementasi vitamin $\mathrm{C}$ dosis rendah diberikan bersamaan dengan penggunaan desferoksamin untuk membantu meningkatkan pengeluaran besi.

Kata kunci: thalassemia, nutrisi, tumbuh kembang.

p enyakit thalassemia membawa banyak sekali masalah bagi pasien, mulai dari kelainan darah dan berbagai organ tubuh akibat proses penyakitnya maupun akibat pengobatan, karena pasien thalassemia berat akan memerlukan transfusi darah seumur hidupnya. Secara klinis dibedakan antara thalassemia mayor dan thalassemia minor. Kasus thalassemia mayor umumnya memberikan gejala klinis yang berat, berupa anemia, hepatosplenomegali, pertumbuhan yang terhambat dan gizi kurang atau gizi buruk. Wahidiyat mendapatkan $22,7 \%$ kasus thalassemia tergolong dalam gizi baik, 64,1\% kurang dan 13,2\% buruk. Gejala anemia bahkan sudah dapat terlihat pada usia kurang dari satu tahun. ${ }^{1}$ Bentuk heterozigot biasanya secara klinis sukar dikenal karena tidak memperlihatkan gejala klinis yang nyata dan umumnya tidak memerlukan pengobatan. ${ }^{1}$

Gangguan pertumbuhan pada pasien thalassemia disebabkan oleh berbagai faktor, antara lain faktor

Dr. Luszy Arijanty: PPDS Ilmu Kesehatan Anak FKUI, Jakarta.

\footnotetext{
Alamat korespondensi:

Dr. Sri S Nasar, SpA(K).

Subbagian Gizi \& Penyakit Metabolik. Bagian Ilmu Kesehatan Anak FKUI-RSCM.

Jl. Salemba no.6, Jakarta 10430 .

Telepon: 021-3915715. Fax,: 021-390 7743.
}

hormonal akibat hemokromatosis pada kelenjar endokrin dan hipoksia jaringan akibat anemia. ${ }^{2,3}$ Faktor lain yang berperan pada pertumbuhan pasien thalassemia adalah faktor genetik dan lingkungan. Nutrisi merupakan faktor lingkungan yang penting dalam mempengaruhi tumbuh kembang anak. Beratnya anemia dan limpa yang besar menyebabkan nafsu makan menurun, sehingga asupan makanan berkurang, berakibat terjadinya gangguan gizi. Bila kadar hemoglobin dipertahankan tinggi, lebih kurang $10 \mathrm{~g} / \mathrm{dL}$, disertai pencegahan hemokromatosis, maka gangguan pertumbuhan tidak terjadi. Gangguan gizi pada thalassemia biasanya belum jelas terlihat pada anak yang berumur kurang dari satu tahun. Anemia dan kekurangan gizi kronis diduga merupakan penyebab perawakan pendek. ${ }^{1,3}$

Di dalam naskah ini akan dibahas mengenai masalah nutrisi pada kasus thalassemia.

\section{Masalah nutrisi pada thalassemia}

Nutrisi merupakan faktor lingkungan yang penting untuk mencapai tumbuh kembang yang optimal; walaupun sangat banyak nutrien yang telah dikenal namun masih belum jelas nutrien mana yang terbukti secara tersendiri mempengaruhi pertumbuhan fisik. Nutrisi mutlak diperlukan oleh setiap mahluk hidup untuk bertumbuh dan berkembang serta berfungsi secara maksimal. ${ }^{4}$ 
Pada thalassemia terjadi proses hemolisis sehingga terjadi anemia kronis yang mengakibatnya hipoksia jaringan. Hipoksia kronis menyebabkan gangguan penggunaan nutrien pada tingkat sel, sehingga terjadi gangguan pertumbuhan. Nutrisi yang optimal sangat penting untuk kasus thalassemia sebagai modalitas dalam pengobatan jangka panjang dan untuk mencegah gangguan gizi, gangguan pertumbuhan, perkembangan pubertas terlambat, dan defisiensi imun yang mungkin berhubungan dengan malnutrisi sekunder. ${ }^{5}$ Asupan nutrisi yang seimbang, mengandung vitamin, serta pemberian suplemen kalsium dan vitamin D yang adekuat, dapat meningkatkan densitas tulang dan mencegah osteoporosis; namun pasien thalassemia harus menghindari makanan dengan kandungan besi tinggi terutama yang berasal dari daging (haem-iron). ${ }^{6,7,8}$

\section{Makronutrien}

Kasus thalassemia pada masa pertumbuhannya memerlukan masukan protein dan kalori yang tinggi, kalori terutama berasal dari karbohidrat, sedangkan lemak cukup diberikan dalam jumlah normal. ${ }^{5,8,9}$ Pemberian kalori untuk thalassemia dianjurkan 20\% lebih tinggi dari pada angka kecukupan gizi harian (AKG). ${ }^{5}$ World Health Organization (WHO) menganjurkan konsumsi lemak sebanyak 15-30\% dari total kalori. Jumlah ini memenuhi kebutuhan asam lemak esensial dan untuk membantu penyerapan vitamin yang larut dalam lemak. ${ }^{10}$ Setelah dewasa masukan karbohidrat sebaiknya dibatasi, sebagai upaya untuk mencegah atau mengatasi intoleransi glukosa. ${ }^{9}$ Tahun 1997 Fuchs di Thailand melakukan penelitian tentang asupan nutrisi pada kasus thalassemia usia 20-36 bulan dengan status gizi kurang yang diberi $150 \mathrm{kalori} / \mathrm{kg}$ berat badan/hari dan protein 4 gram/kg berat badan/ hari selama 1 bulan. Hasilnya terjadi peningkatan berat badan yang bermakna, yaitu sekitar 1,2 kg. ${ }^{5}$

\section{Mikronutrien}

Mikronutrien terdapat dalam jumlah sangat sedikit dalam tubuh, namun mempunyai peran yang penting dalam pemeliharaan fungsi tubuh, baik pada tingkat selular, jaringan, organ, maupun fungsi tubuh secara keseluruhan. ${ }^{10}$

\section{Besi}

Transfusi darah terus menerus pada pasien thalassemia dapat mengakibatkan penimbunan besi dalam tubuh dan terjadinya hemosiderosis. Untuk mengurangi penimbunan besi yang terlalu cepat dapat dipergunakan desferoksamin, di samping itu juga dengan pemberian nutrisi rendah besi. ${ }^{9,11,12}$ Pemberian besi dalam bentuk elemen pada pasien thalassemia berusia di bawah 10 tahun sebaiknya dibatasi maksimal 10 $\mathrm{mg} /$ hari, sedangkan di atas 10 tahun dibatasi maksimal $18 \mathrm{mg} /$ hari. Kebutuhan besi untuk anak-anak normal rata-rata $18 \mathrm{mg} /$ hari. $^{13}$

Kesulitan memantau diet pada anak merupakan masalah yang sering dijumpai, oleh sebab itu maka yang penting adalah membina pola makan yang baik pada mereka. Anak harus diingatkan untuk menghindari makanan dengan kandungan besi tinggi seperti hati, daging merah atau produk lainnya. Besi dari sumber hewani lebih mudah diserap daripada sumber lain seperti sereal dan roti. Ikan merupakan sumber protein dengan kandungan besi rendah. ${ }^{11,21}$ Sebaiknya dihindari memasak dengan alat masak dari besi, karena besi dari alat masak tersebut dapat berpindah ke makanan. Minuman dengan kandungan vitamin C tinggi seperti jus jeruk dapat meningkatkan absorbsi besi, sedangkan teh dan kopi dapat menghambat absorbsi besi bila dikonsumsi pada saat makan atau 1 jam setelah makan. ${ }^{13,14,15}$ lain, ${ }^{13}$

Makanan yang mengandung zat besi tinggi antara

- Protein: kerang, hati, daging babi, kacangkacangan, daging sapi, selai kacang, tahu

- Tepung: tepung tortila, sereal bayi, krim gandum, sereal

- Buah dan sayuran: semangka, bayam, sayuran hijau, kismis, brokoli, buah prune

\section{Seng}

Absorpsi dan metabolisme seng menyerupai absorpsi dan metabolisme besi. Sebagian seng menggunakan transferin sebagai alat transport, yang juga merupakan alat transport besi. Bila perbandingan antara besi dengan seng lebih dari $2: 1$, transferin yang tersedia untuk seng berkurang, sehingga menghambat absorpsi seng. Sebaliknya seng dosis tinggi juga menghambat absorpsi besi ${ }^{14}$. Pada thalassemia, kadar besi yang tinggi dapat menghambat absorpsi seng karena diabsorbsi pada sel mukosa usus yang sama, yaitu pada jejunum dan ileum, serta menggunakan transferin sebagai alat transport. Seluruh seng yang diabsorpsi masuk ke 
dalam sirkulasi darah, disimpan dalam berbagai jaringan tubuh, terutama di dalam otot dan tulang, kemudian diekskresi melalui saluran cerna. ${ }^{14,15}$ Defisiensi seng yang berat pada thalassemia dapat menyebabkan gangguan pertumbuhan, hambatan maturasi seksual, hipogonadisme, alopesia, defisiensi imun, serta hambatan pada proses penyembuhan luka. ${ }^{4,14,17}$ Defisiensi seng yang kronis mengakibatkan penurunan produksi somatomedin. ${ }^{14}$ Penelitian menunjukkan bahwa suplementasi seng pada bayi dan anak dengan hambatan pertumbuhan menyebabkan pertumbuhan linier lebih cepat. ${ }^{4,15,17}$ Makanan dengan kadar seng tinggi antara lain kerang, daging merah, sereal, sedangkan telur, susu dan ikan mengandung seng dalam jumlah yang lebih sedikit. ${ }^{16,17}$ Suplementasi seng pada thalassemia sebaiknya dengan dosis tinggi yaitu $45 \mathrm{mg} /$ hari. $^{14}$

\section{Kalsium}

Kalsium diperlukan untuk membentuk dan mempertahankan kekuatan tulang dan gigi. Bila kadar kalsium dalam darah rendah, tubuh akan meningkatkan produksi hormon paratiroid yang berfungsi merangsang pelepasan kalsium dari tulang dan reabsorpsi kalsium dalam ginjal untuk mempertahankan kadar kalsium dalam darah. Absorpsi kalsium pada saluran cerna juga akan ditingkatkan dengan pemberian vitamin D. Bila asupan kalsium dalam makanan kurang, maka deposit kalsium dalam tulang akan menurun dan pelepasan kalsium dari tulang akan semakin meningkat, mengakibatkan terjadinya osteoporosis. ${ }^{10}$ Selain hormon paratiroid dan vitamin D, densitas tulang juga dipengaruhi oleh hormon tiroksin, estrogen dan testosteron.

Pada pasien thalassemia yang tidak mendapatkan transfusi darah secara adekuat terjadi peningkatan aktifitas sumsum tulang, sehingga korteks tulang menjadi tipis. ${ }^{14,18}$ Sebaliknya, pemberian transfusi berulang akan menyebabkan terjadinya hemosiderosis pada berbagai organ seperti testis, ovarium, kelenjar tiroid dan paratiroid dengan akibat menurunnya densitas tulang pula; oleh karena itu selain pemberian desferoksamin diperlukan pula terapi hormon dan suplementasi kalsium. ${ }^{18}$

Pemberian kalsium pada thalassemia dianjurkan kurang lebih 1 gram perhari. Pada remaja kebutuhan akan meningkat menjadi 1,5 sampai 2 gram perhari. ${ }^{14,18}$
Makanan mengandung sumber kalsium tinggi adalah susu, yoghurt, keju, puding susu, sarden dengan tulangnya. Makanan dengan kadar kalsium sedang antara lain tahu, kacang-kacangan, brokoli, mustard, pok choy, keju, es krim, dan almond. Kalsium juga dapat ditemukan pada sayuran seperti brokoli, serta produkproduk yang diperkaya dengan kalsium seperti jus jeruk, roti dan susu kedelai ${ }^{18}$.

\section{Vitamin C}

Vitamin C merupakan bahan esensial yang diperlukan tubuh untuk membentuk jaringan penunjang (connective tissue), juga diperlukan untuk penyerapan besi dari makanan, serta berperan pada metabolisme besi. Defisiensi vitamin C menyebabkan scurvy, dengan gejala pada mulut / gusi mudah memar, perdarahan mukosa dan anemia. Telah diketahui bahwa vitamin C dapat menyembuhkan scurvy dan meningkatkan kadar besi dalam plasma. ${ }^{10,19}$

Vitamin $\mathrm{C}$ dapat membantu meningkatkan kerja desferoksamin untuk mengeluarkan besi sampai dua kali lipat, namun ditemukan bahwa pemberian desferoksamin yang disertai pemberian vitamin C $500 \mathrm{mg}$ perhari dapat mengakibatkan menurunnya fungsi jantung. Hal ini disebabkan karena vitamin $\mathrm{C}$ akan meningkatkan kadar besi yang aktif di dalam sel (mengubah feritin menjadi transferin), sehingga meningkatkan jumlah besi untuk dikelasi oleh desferoksamin; terlalu banyak besi bebas dapat menyebabkan peroksidasi membran lipid sehingga menimbulkan efek toksik pada jantung dan organ lainnya. Oleh karena itu dianjurkan pemberian vitamin $\mathrm{C}$ dosis rendah yaitu $100-250 \mathrm{mg} / \mathrm{hari}$ atau $3 \mathrm{mg} / \mathrm{kg}$ berat badan/ hari, diberikan setelah infus desferoksamin dimulai. ${ }^{14,17,19,20}$

\section{Vitamin D}

Fungsi utama vitamin D membantu pembentukan dan pemeliharaan tulang dengan cara mengatur agar kalsium dan fosfat tersedia di dalam darah untuk diendapkan pada proses pengerasan tulang. Hal ini dilakukan dengan cara sebagai berikut: ${ }^{21}$

- Pada saluran cerna kalsitriol meningkatkan absorpsi aktif kalsium dengan cara merangsang sintesis protein pengikat kalsium dan protein pengikat fosfor pada mukosa usus halus. 
- Pada tulang kalsitriol bersama hormon paratiroid merangsang pelepasan kalsium dari permukaan tulang ke dalam darah.

- Pada ginjal kalsitriol merangsang reabsorpsi kalsium dan fosfor.

Vitamin D banyak ditemukan pada kuning telur, hati, krim, mentega dan minyak hati ikan cod. Susu sapi dan ASI bukan merupakan sumber vitamin D yang baik. Untuk menjamin terpenuhinya kebutuhan vitamin D dilakukan fortifikasi makanan, terutama pada susu, mentega, dan produk makanan untuk bayi. ${ }^{14,22}$

Pasien thalassemia yang mendapat transfusi darah berulang biasanya memiliki kadar vitamin D yang rendah sebagai akibat disfungsi hati. Bila sudah terjadi osteoporosis dianjurkan pemberian vitamin D dengan dosis yang lebih tinggi, 800-1000 unit perhari. Efek samping pemberian vitamin $\mathrm{D}$ dan kalsium yang terlalu tinggi adalah hiperkalsiuria dan hiperkalsemia. ${ }^{22}$ Pasien thalassemia mayor dianjurkan melakukan pemeriksaan densitas tulang, kadar hormon paratiroid, kadar 1,25 dihidroksi vitamin D serta tanda-tanda terjadinya hipogonadisme. ${ }^{22}$ Evaluasi densitas tulang mulai dilakukan setelah pasien berusia 13 tahun pada anak perempuan dan usia 15 tahun pada anak laki-laki. Sedangkan evaluasi kadar hormon paratiroid, tes toleransi glukosa oral, kadar $\mathrm{TSH}$, dan $\mathrm{T}_{4}$ dapat dilakukan mulai usia 10 tahun, selanjutnya dapat diulang setiap 2 tahun. Evaluasi fungsi jantung dan ginjal sebaiknya juga dilakukan setiap 3 bulan, terutama bila kadar feritin di atas $2000 \mathrm{ng} / \mathrm{ml} .^{22,23}$

\section{Vitamin E}

Fungsi utama vitamin $\mathrm{E}$ adalah sebagai antioksidan dengan cara memberikan hidrogen dari gugus hidroksil $(\mathrm{OH})$ pada struktur cincin ke radikal bebas. Radikal bebas adalah molekul-molekul reaktif yang dapat merusak jaringan tubuh. Radikal bebas ini mempunyai elektron tidak berpasangan dan bila menerima ion hidrogen, radikal bebas menjadi tidak reaktif. Vitamin E berada pada lapisan fosfolipid membran sel dan berperan melindungi asam lemak tidak jenuh ganda dan komponen membran sel lain dari oksidasi oleh radikal bebas. Membran sel utama terdiri atas asam lemak tidak jenuh ganda yang sangat mudah dioksidasi oleh radikal bebas. Proses peroksidasi lipid ini dapat menyebabkan kerusakan struktur dan fungsi membran sel. Reaksi ini dipercepat oleh besi dan tembaga, serta dapat dicegah bila radikal bebas diikat oleh antioksidan. ${ }^{10}$ Peran biologik utama vitamin E adalah memutuskan rantai proses peroksidasi lipid dengan menyumbangkan satu atom hidrogen dari gugus $\mathrm{OH}$ pada cincinnya ke radikal bebas, sehingga terbentuk ikatan radikal vitamin E yang stabil dan tidak merusak. ${ }^{10,21}$ Pada thalassemia vitamin E berfungsi sebagai antioksidan, menghambat peroksidasi membran sel sehingga dapat melindungi sel dari efek toksisitas besi, melindungi asam lemak tidak jenuh terhadap serangan radikal bebas, serta melindungi sel darah merah terhadap proses hemolisis. ${ }^{8,24}$

Sumber utama vitamin E adalah tumbuhtumbuhan, terutama kecambah, gandum, dan bijibijian. Minyak kelapa dan zaitun hanya sedikit mengandung vitamin E. Sayur dan buah-buahan juga merupakan sumber vitamin E yang baik. ${ }^{10}$ Dosis vitamin E yang dianjurkan pada orang dewasa adalah 200-400 IU/ hari, sedangkan pada anak $1 \mathrm{IU} / \mathrm{kgBB}$ per kali. ${ }^{14}$ Antioksidan lain seperti vitamin A (,karoten), seng, dan selenium, juga sangat berguna untuk melindungi sel-sel dari efek peroksidasi besi pada membran sel. ${ }^{24}$

\section{Asam folat}

Pada pasien thalassemia yang tidak mendapat transfusi secara adekuat biasanya terjadi defisiensi asam folat, akibat peningkatan eritropoiesis serta asupan asam folat yang rendah. ${ }^{8,9,14}$ Asam folat digunakan untuk sintesis DNA, maka pada thalassemia diperlukan dalam jumlah besar untuk mempercepat proses regenerasi sel; dosis yang dianjurkan $1 \mathrm{mg}$ per hari. ${ }^{9,14}$

\section{Pengaturan nutrisi pada thalassemia}

Berdasarkan berbagai hal yang telah diuraikan di atas, maka asupan nutrisi yang dianjurkan pada pasien thalassemia adalah tinggi kalori, tinggi protein, kalsium, seng, vitamin A (,-karoten), vitamin D, vitamin $\mathrm{E}$, dan rendah besi, sedangkan vitamin $\mathrm{C}$ harus dibatasi karena dapat meningkatkan absorpsi besi. Berikut ini contoh anjuran nutrisi yang diberikan pada penderita thalassemia di RSU Serawak. ${ }^{24}$ (Tabel 1 dan 2) 
Tabel 1. Makanan yang harus dihindari oleh pasien thallassemia. ${ }^{24}$

\begin{tabular}{ll}
\hline $\begin{array}{l}\text { Makanan dengan kandungan } \\
\text { besi tinggi }\end{array}$ & Kandungan besi \\
\hline - Organ dalam (hati, ginjal, limpa) & $5-14 \mathrm{mg} / \mathrm{dl} / 100 \mathrm{~g}$ \\
- Daging sapi & $2,2 \mathrm{mg} / 100 \mathrm{~g}$ \\
- Hati dan ampela ayam & $2-10 \mathrm{mg} / 100 \mathrm{~g}$ \\
- Ikan pusu (dengan kepala & \\
& \\
- dan tulang) & $5,3 \mathrm{mg} / 100 \mathrm{~g}$ \\
- Kerang & $13,2 \mathrm{mg} / 100 \mathrm{~g}$ \\
- Telur ayam & $2,4 \mathrm{mg} / \mathrm{butir}$ \\
- Buah kebek & $3,7 \mathrm{mg} / \mathrm{butir}$ \\
- Kacang-kacangan yang digoreng & $4-8 \mathrm{mg} / 100 \mathrm{~g}$ \\
- Kacang-kacangan yang dibakar & $1,9 \mathrm{mg} / 100 \mathrm{~g}$ \\
- Biji-bijian yang dikeringkan & $21,7 \mathrm{mg} / 100 \mathrm{~g}$ \\
- Sayuran berwarna hijau (bayam, & \\
& kailan, kangkung)
\end{tabular}

Tabel 2. Makanan yang diperbolehkan bagi pasien thallassemia. ${ }^{24}$

\begin{tabular}{ll}
\hline $\begin{array}{l}\text { Makanan dengan kandungan } \\
\text { besi sedang }\end{array}$ & Jumlah pemberian \\
\hline - Daging ayam, daging babi & 2 potong/hari \\
- Tahu & 1 potong \\
- Sawi, kacang panjang & $1-2$ porsi $(0,5$ cup $) / h a r i$ \\
- Ikan pusu & tanpa kepala dan tulang \\
- Bawang, gandum & jumlah sedang \\
\hline
\end{tabular}

Makanan dengan kandungan

besi rendah

- Nasi, mie, roti, biskuit

- Umbi-umbian (wortel, lobak, bengkoang)

- Semua jenis ikan

- Semua jenis buah (yang tidak dikeringkan)

- Susu, keju, minyak, lemak

\section{Daftar Pustaka}

1. Wahidiyat I. Penelitian thalassemia di Jakarta. Tesis. Jakarta: Intermega, 1979.

2. De Sanctis V, Tangerini A, Lauriola L, Bellettati S. Growth endocrine complications and reproduction in thalassemia major. Didapat dari: http://www.mdconsult.com/

3. Spiliotis BE. $\beta$-thalassemia and normal growth: are they compatible? Eur J of endocrinology, 1998, 139:143-4.

4. Nasar SS. Aspek gizi pada anak dengan perawakan pendek. Dalam: Rukman Y, Batubara J, Tridjaja B, penyunting. Masalah penyimpangan pertumbuhan somatik pada anak dan remaja. Naskah lengkap PKBIKA XXVIII. FKUI. 1993 16-17 Februari. Jakarta; Balai Penerbit FKUI; 1993. h. 63-72.

5. Fuchs GJ, Tienboon P, Khaled MA, Nimsakul S, Linpisarn S, Faruque ASG. Nutritional support and growth in thalassemia major. Arch dis 1997; 76:509-12.

6. Tiosano D, Hochbrgz. Endocrine complication in patients beta-thalassemia major. J Endocrinol Invest, Haifa, Israel, 2001; 24:716-23.

7. Williams R, George EO, Wang W. Nutrition assessment in children with sickle cell disease. J Assoc Acad Minor Phys, Tenessee, USA, 1997; 8:44-8.

8. Kuvibidila S, Warrier RP. Nutritional support of children with sickle cell disease and thalassemia. Dalam: Suskind RM, Suskind LL, penyunting. Textbook of pediatric nutrition. Edisi ke-2. New York: Raven Press. 1993. h. 425-36.

9. Vullo R, Modell B, Georganda E. Guidelines for clinical management of thalassemia. Edisi ke-2. Nicosia: Thalassemia International Federation, 1995. h. 26-53.

10. Almatsier S. Vitamin. Dalam: Prinsip dasar ilmu gizi. Edisi pertama. Jakarta: PT. Gramedia Pustaka Utama, 2001. h. 167-73.

11. Oliveri NF, De Silva S, Premawardena A, Sharma S, Viens AM, Taylor CM, et all. Iron overloaded and iron chelating therapy in hemoglobin E-beta thalassemia. J Pediatr Hematol Oncol, Canada, 2000; 22:593-7.

12. Angelucci E, Brittenham GM, McLaren CE, Ripalti M, Baronciani D, Giardini C, et all. Hepatic iron concentration and total body iron stores in thalassemia major. N Engl J med, 2000; 343:327-31.

13. Low iron diet for chronically-transfused patient. Didapat dari http://www.thalassemia.com/transfusion/iron.shtm/.

14. Almatsier S. Mineral mikro. Dalam: Prinsip dasar ilmu gizi. Edisi pertama. Jakarta: PT. Gramedia Pustaka Utama, 2001. h. 249-57

15. King JC, Keen CL. Zinc. Dalam: Modern nutrition in health and disease. Edisi ke-9. Philadelphia: Lippincott Williams\&Wilkins, 1998. h. 223-37.

16. NIH Clinical center. Zinc. Didapat dari: http:// www.nal.usda.gov/fnicletext/000020.html.

17. Zemel BS, Kawchak DA, Fung EB, Stallings VA. Effect of zinc supplementation on growth and body composition in children with sickle cell disease. Am J of Clin Nutr, 2002; 75:300-7.

18. Calcium and Thalassemia. Didapat dari http:// www.thalassemia.com/

19. The vitamin C/ferritin/iron connection. Didapat dari http://www.thalassemia.com/

20. Brittenham GM, Griffith PM, Nienhuis AW. Efficacy of deferoxamine in preventing complication of iron overloaded in patients with thalassemia major. $\mathrm{N}$ Engl J med, 2000; 33:567-73.

21. Combs GF. Vitamin D. Dalam: Combs GF, penyunting. The Vitamins, fundamental aspects in nutrition and health. San Diego, Academic press Inc. 1992. h.151-78.

22. Vitamin D and osteoporosis. Didapat dari http:// www.thalassemia.com/

23. Assessment of iron overload. Didapat dari http:// 
www.thalassemia.com/

24. Thalassaemia diet. Didapat dari http://www.altavista.com/

25. Weatherall DJ, Clegg JB. The b thalassemias. Dalam: Gibbons R, Higgs DR, Old JM, Oliveri NF, Thein SL, Wood WG, penyunting. The thalassemia syndromes. Blackwell science Ltd, London, 2001. h. 287-344.

26. Mc Donagh KT, Nienhuis AW. The Thalassemias. Dalam: Nathan DG, Oski FA, penyunting. Hematology of infancy and childhood. Edisi ke-4. Philadelphia: WB Saunders company,1993. h. 783-880.

27. Yaish HM. Thalassemia. eMedicine Journal, November 27 2001, Volume 2, Number 11. Didapat dari: http// www.emedicine.com.

28. Vullo R, Modell B, Georganda E. Guidelines for clinical management of thalassemia. Edisi ke-2. Nicosia: Thalassemia International Federation, 1995. h. 26-53.

29. Oliveri NF, De Silva S, Premawardena A, Sharma S, Viens AM, Taylor CM, et all. Iron overloaded and iron chelating therapy in hemoglobin E-beta thalassemia. J Pediatr Hematol Oncol, Canada, 2000; 22:593-7.

30. Fairbanks VF. Iron in medicine and nutrition. Dalam: Modern nutrition in health and disease. Edisi ke-9. Philadelphia: Lippincott Williams\&Wilkins, 1998. h. 193-219.

31. Lauffer RB. Preventive measures for the maintenance of low but adequate iron store. Dalam: Lauffer RB, penyunting. Iron and human disease. Florida: CRC Press, Inc. 1992. h. 460-74.

32. Tiosano D, Hochbrgz. Endocrine complication in patients beta-thalassemia major. J Endocrinol Invest, Haifa, Israel, 2001; 24:716-23.

33. WHO Working Group. Use and interpretation of anthropometric indicators of nutritional status. Bulletin of the World Health Organization, 1986, 64: 929-41.

34. Fuchs GJ, Tienboon P, Khaled MA, Nimsakul S, Linpisarn S, Faruque ASG. Nutritional support and growth in thalassemia major. Archives of disease in childhood 1997; 76:509-12.

35. Nasar SS. Aspek gizi pada anak dengan perawakan pendek. Dalam: Rukman Y, Batubara J, Tridjaja B, penyunting. Masalah penyimpangan pertumbuhan somatik pada anak dan remaja. Naskah lengkap PKBIKA XXVIII. FKUI. 1993 16-17 Februari. Jakarta; Balai Penerbit FKUI; 1993. h. 63-72.

36. Williams R, George EO, Wang W. Nutrition assessment in children with sickle cell disease. J Assoc Acad Minor Phys, Tenessee, USA, 1997; 8:44-8.
37. Kuvibidila S, Warrier RP. Nutritional support of children with sickle cell disease and thalassemia. Dalam: Suskind RM, Suskind LL, penyunting. Textbook of pediatric nutrition. Edisi ke-2. New York: Raven Press. 1993. h. 425-36.

38. Walker WA, Hendricks KM. Estimation of energy needs. Dalam: Walker WA, Hendricks KM, penyunting. Manual of pediatric nutrition. Philadelphia: WB Saunders Company. 1985. h. 52-62.

39. Almatsier S. Vitamin. Dalam: Prinsip dasar ilmu gizi. Edisi pertama. Jakarta: PT. Gramedia Pustaka Utama, 2001. h. 167-73.

40. Angelucci E, Brittenham GM, McLaren CE, Ripalti M, Baronciani D, Giardini C, et all. Hepatic iron concentration and total body iron stores in thalassemia major. N Engl J med, 2000; 343:327-31.

41. Low iron diet for chronically-transfused patient. Didapat dari http://www.thalassemia.com/transfusion/iron.shtm/.

42. Almatsier S. Mineral mikro. Dalam: Prinsip dasar ilmu gizi. Edisi pertama. Jakarta: PT. Gramedia Pustaka Utama, 2001. h. 249-257

43. King JC, Keen CL. Zinc. Dalam: Modern nutrition in health and disease. Edisi ke-9. Philadelphia: Lippincott Williams\&Wilkins, 1998. h. 223-237.

44. NIH Clinical center. Zinc. Didapat dari: http:// www.nal.usda.gov/fnicletext/000020.html.

45. Zemel BS, Kawchak DA, Fung EB, Stallings VA. Effect of zinc supplementation on growth and body composition in children with sickle cell disease. Am J of Clin Nutr, 2002; 75:300-307.

46. Calcium and Thalassemia. Didapat dari http:// www.thalassemia.com/

47. The vitamin C/ferritin/iron connection. Didapat dari http://www.thalassemia.com/

48. Combs GF. Vitamin D. Dalam: Combs GF, penyunting. The Vitamins, fundamental aspects in nutrition and health. San Diego, Academic press Inc. 1992. h. 151-781.

49. Brittenham GM, Griffith PM, Nienhuis AW. Efficacy of deferoxamine in preventing complication of iron overloaded in patients with thalassemia major. N Engl J med, 2000; 331:567-573.

50. Vitamin D and osteoporosis. Didapat dari http:// www.thalassemia.com/

51. Assessment of iron overload. Didapat dari http:// www.thalassemia.com/

52. Thalassaemia diet. Didapat dari http://www.altavista.com/ 